\title{
Articulated hyoliths and other fossils from the Sirius Passet Lagerstätte (early Cambrian) of North Greenland
}

\author{
JOHN S. PEEL
}

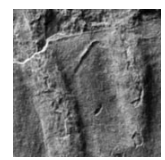

\begin{abstract}
Hyolithids with helens and an operculum, and a second species of loricate cycloneuralian, Sirilorica pustulosa sp. nov., are described from the Sirius Passet Lagerstätte (early Cambrian; Cambrian Series 2, Stage 3) of Peary Land, North Greenland. An ethmophylloid archaeocyathan and a species of the bivalved arthropod Isoxys are described in open nomenclature. The association of trace fossils with body fossils is discussed. $\bullet$ Key words: Cambrian, Lagerstätte, Greenland, Hyolitha, Cycloneuralia, trace fossils.
\end{abstract}

PEEL, J.S. 2010. Articulated hyoliths and other fossils from the Sirius Passet Lagerstätte (early Cambrian) of North Greenland. Bulletin of Geosciences 85(3), 385-394 (5 figures). Czech Geological Survey, Prague. ISSN 1214-1119. Manuscript received August 16, 2010; accepted in revised form August 30, 2010; published online September 10, 2010; issued September 30, 2010.

John S. Peel, Department of Earth Sciences (Palaeobiology), Uppsala University, Villavägen 16, SE-75 236 Uppsala, Sweden;John.Peel@pal.uu.se

In the quarter of a century that has passed since the first recognition of the early Cambrian Sirius Passet Lagerstätte (Conway Morris et al. 1987, Babcock \& Peel 2007, Peel \& Ineson in press), some 20 new species have been described from the highly innaccessible locality on the northernmost shore of Greenland (latitude $82^{\circ} 47.6^{\prime} \mathrm{N}$, longitude $42^{\circ} 13.3^{\prime} \mathrm{W}$; Fig. 1). This paper adds to these by describing several rare or poorly preserved taxa, and an association of trace fossils with a body fossil. The material was collected during expeditions to North Greenland in 1989, 1991, 1994 and 2006 from talus accumulating below a succession of about $8 \mathrm{~m}$ of black shale and laminated mudstones of the Buen Formation that abut the steep outer margin of the eroded carbonate platform of the Portfjeld Formation (Ineson \& Peel 1997, in press; Peel \& Ineson in press).

It is estimated that the biota contains about 40 species and those described to date are listed in Fig. 1B. The assemblage is dominated by arthropods and lobopods, with abundant shields of the bivalved arthropod Isoxys volucris (Williams et al. 1996, Stein et al. 2010) and articulated exoskeletons of the trilobite Buenellus higginsi (Blaker \& Peel 1997, Babcock \& Peel 2007); an additional species of Isoxys is described herein. Trilobite-like arthropods (some as yet undescribed) are also conspicuous. Many arthropod and lobopod specimens show preservation of appendages, musculature and internal organs (Budd 1993, 1995, 1997, 1998, 1999a, b; Taylor 2002; Lagebro et al. 2009; Peel \& Stein 2009; Stein 2010). Other fossils include polychaete and palaeoscolecidan worms (Conway Morris \& Peel 2008,
2010) and articulated halkieriids (Conway Morris \& Peel 1990, 1995; Vinther \& Nielsen 2005; Conway Morris \& Caron 2007). Peel (2010) described the loricate cycloneuralian Sirilorica carlsbergi and a second species of the genus is described herein. Arthropods apart, sponges are conspicuous amongst the undescribed faunal elements; brachiopods, helcionelloid molluscs and echinoderms are absent. New elements reported here include hyoliths, some with helens, and an ethmophylloid archaeocyathan.

In browsing the abundant literature concerning the biota of Cambrian lagerstätten such as Chengjiang (Hou et al. 1999, 2004; Luo et al. 1999; Chen 2004) and the Burgess Shale (Briggs et al. 1994, Conway Morris 1998), it is easy to forget that the exceptional preservation displayed by so many animal groups is not offered equally to all, even in these special preservational environments. Thus, hyolithids form a small, crushed, but otherwise well preserved, element of the Burgess Shale fauna; they are often fully articulated, with operculum and helens preserved in place (Yochelson 1961, Babcock \& Robison 1988). Members of the Class Hyolitha may be very common at Chengjiang but articulated hyolithids with helens are not reported. Some specimens are associated with opercula and have been interpreted as hyolithids or orthothecids (helens are present in hyolithids but not in orthothecids) (Chen 2004, fig. 308).

Less than 20 specimens of hyoliths are currently known from the Sirius Passet Lagerstätte and some are described herein. While several preserve life associations of conch, operculum and the paired helens, their general poor state of 


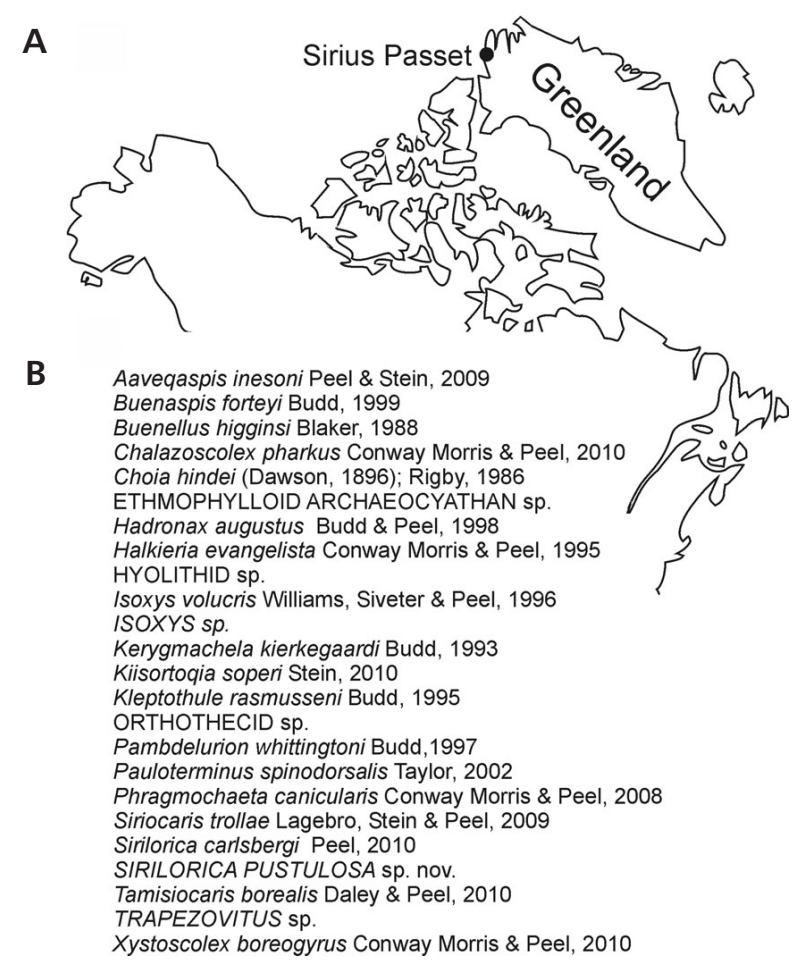

Figure 1. Location of the Sirius Passet Lagerstätte in North Greenland (A). The faunal list (B) includes all described taxa, with those from the present paper in upper case.

preservation precludes precise determination, despite their originally hard external skeleton. Their calcareous shells and three-dimensional sediment infilling are crushed or partly crushed in mudstone and preserved as composite moulds and impressions with no trace of the original shell and little detail of ornamentation. The presumed originally aragonitic hyolith shells were clearly less resistant to diagenetic processes than other calcareous fauna, such as trilobites, halkieriids and the rare archaeocyathans.

Mineral growth has taken place as irregular aggregates in the apertural region in some hyolith specimens, probably as an early diagenetic process similar to the mineralization of gut diverticula and muscle fibres characteristic of many Sirius Passet arthropods ( $c f$. Budd 1998, Babcock \& Peel 2007). It is also a feature of many Sirius Passet arthropod specimens that while elements of the body cavity may be preserved in fine three-dimensional detail due to early diagenetic mineralization, distal extremities simply fade into the surrounding sediment. Additionally, as discussed below, assemblages of burrows preserved in association with body fossils often show enhanced three-dimensional preservation within the area of the body fossil.

Specimen depositories. - All illustrated specimens carry MGUH numbers indicating their deposition in the type collection of the Geological Museum, Copenhagen, Denmark, now a part of the Natural History Museum of Denmark.

\section{Trace fossils}

The association of body fossils and three-dimensionally preserved trace fossils (burrows) is a conspicuous feature of the Sirius Passet Lagerstätte (Fig. 2). Conway Morris \& Peel (1995) considered the association of traces with Halkieria evangelista to be fortuitous; the horizontal burrows have been impressed on the Halkieria specimens from both higher and lower sedimentary levels. Budd (1999b) referred to body-trace fossil interaction but without elaboration. Babcock \& Peel (2007) noted that the behaviour of the horizontal burrows was sometimes controlled by the shape of skeletal elements, although they suggested it could be as a response to physical hindrance rather than scavenging. They concluded that the trace fossils may have mined nutrients associated with both the decaying animal soft parts or with biofilms developed around them. Alternatively, trace fossils may have been selectively mineralized in the organic rich sediments associated with the cadavers. Peel \& Stein (2009) illustrated narrow burrows traversing compactional folding in the arthropod Aaveqaspis inesoni without deflection, indicating that the burrows were formed after compaction.

One specimen of an undescribed arthropod illustrated here (Fig. 2) presents a varied association of burrows. The largest burrows (width $\mathrm{ca} 2.5 \mathrm{~mm}$ ) form a size class seen in many other specimens and they also occur in the sediment surrounding the body fossils, albeit usually less conspicuously (Fig. 2A, arrow 1). Narrower burrows are less easily traced beyond the tergite margin and most are concentrated to its area. Damage to the tergites resulting from the activities of trace fossil-forming animals is limited to compactional distortion against the infilled larger burrows (Fig. 2A, arrow 2, Fig. 2D).

The largest burrows are sinuous and infrequent $\mathrm{T}$-junction branching (compare Wang et al. 2009, fig. 3A) has been observed in other specimens. When observed beyond the margins of body fossils they are often much less sinuous. They may be impressed by compaction into the tergites from below (Fig. 2D) or from above (Fig 2A, arrow 3) and variation in their expression suggests changes in their level within the sediment. In some cases, the distinctive tergite ornamentation can be traced over the impressed burrow, indicating folding of the tergite during compaction (Fig. 2E, arrow 4). Internally, the large burrows sometimes appear more granular than the surrounding sediment. This fill, and even the outer surface, sometimes shows a longitudinal ('spicular' or nodulose) texture, in some cases possibly formed by faecal pellets.

Smaller burrows are mainly preserved in positive relief and range from $0.1 \mathrm{~mm}$ to about $1 \mathrm{~mm}$ in width; they are irregularly sinuous to straight, with infrequent simple branching (Fig. 2B, E). In some cases their direction is clearly controlled by the arthropod body fossil (e.g. Fig. 2E, arrow 5 where the burrow follows the tergite 

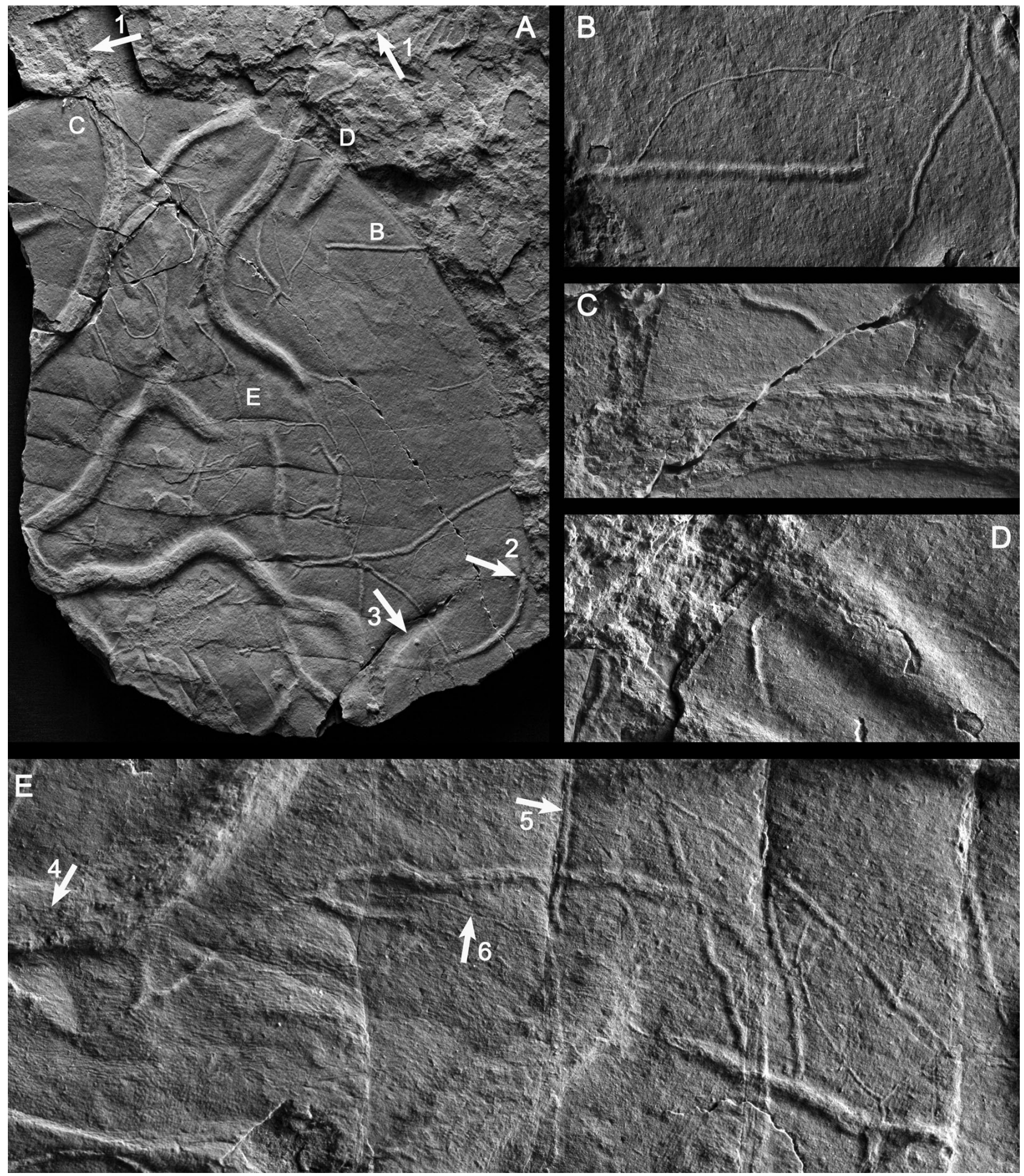

Figure 2. Trace fossil assemblage associated with arthropod shield. MGUH 28755. • A - dorsal view of shield, showing the location of Fig. 2B-E; for explanation see text. Trace fossils are preserved in positive relief except for the impressed burrow (arrow 3$), \times 1.2$. B $\times 3.5$. C $\times 4$. $\bullet D-$ vaulting and cracking of shield against underlying trace, $\times 5 . \bullet E-$ finely ornamented head shield and tergites, overlapping from left to right, $\times 5.5$. Sirius Passet Lagerstätte, Buen Formation, Sirius Passet, Peary Land, North Greenland. 


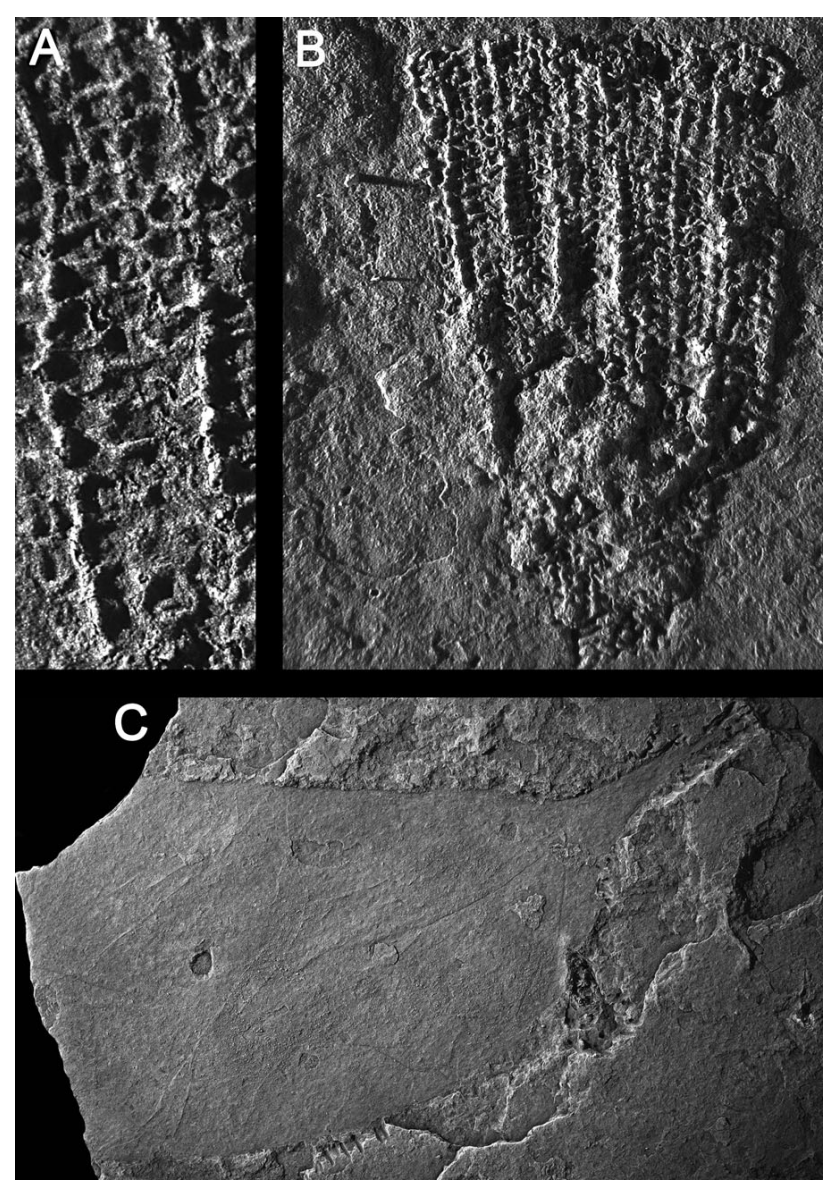

Figure 3. A, B - ethmophylloid archaeocyathan sp., MGUH 29253, crushed cup in lateral view $(B, \times 6)$, with detail of outer wall $(A, \times 16)$. - C - Isoxys sp., MGUH 29255, × 1.5. Sirius Passet Lagerstätte, Buen Formation, Sirius Passet, Peary Land, North Greenland.

margin). Other burrows make use of tergite boundaries to move from above the tergites to below them (or vice versa; Fig. 2A, arrow 2). Figure 2E (arrow 6) shows a $0.1 \mathrm{~mm}$ wide burrow crossing the first tergite but disappearing at the anterior and posterior margins (left and right in the figure). Most of the smaller burrows appear smooth, but a few may be annulated (Fig. 2B, left).

Whilst the increased sinuous character of the larger burrows within the margins of the shield relative to within surrounding sediment suggests a causual relationship, such is more apparent with regard to the narrow traces. The producers of the burrows are not known. Conway Morris \& Peel $(2008,2010)$ described polychaetes and palaeoscolecidans from the Sirius Passet Lagerstätte but illustrated specimens are several times larger than the largest burrows figured here (Fig. 2A).

Similar associations of body fossils and trace fossils have been described from the contemporaneous Chengjiang Lagerstätte by Zhang et al. (2007) and from the middle Cambrian of Bohemia by Chlupáč \& Kordule (2002). Wang et al. $(2004,2009)$ described the interaction between non- mineralized body fossils from the middle Cambrian Kaili Lagerstätte and gordiid burrows of similar size and form to the largest burrows figured here (see also Lin et al. (2010). Caron (2006) and Mángano \& Caron (2009) reported similar occurrences from the middle Cambrian Burgess Shale. All the occurrences seem to combine feeding benefits for the burrowers based on nutrient enriched sediments associated with body fossil cadavers with taphonomic processes favourable for preservation, such as early consolidation/mineralization facilitated by an organic rich environment. The latter, at least, draws attention to a community of organisms otherwise poorly discernible in the lagerstätten sediments.

\section{Systematic palaeontology}

Phylum Porifera Grant, 1836

Class Archaeocyatha Bornemann, 1884

Order Ajacicyathida Bedford \& Bedford, 1939

\section{Ethmophylloid archaeocyathan sp.}

Figure 3A, B

Figured specimen. - MGUH 29253 from Geological Survey of Greenland sample 340103, Sirius Passet, Peary Land, North Greenland.

Discussion. - Fragments of flattened archaeocyathan cups occur sporadically within the Sirius Passet Lagerstätte and a representative example is figured here. In this, the radial septa extend slightly beyond the outer wall and are separated by three rows of sub-rectangular pores (Fig. 3A, B). Andrej Y. Zhuravlev (written communication 2010) identified the specimen as an ethmophylloid archaeocyathan of late Atdabanian-middle Botomian age (Cambrian Series 2, Stage 3) which is in accordance with the Nevadella Zone age of North American usage suggested by the occurrence of Buenellus higginsi. The figured specimen and others in the collection are broken proximally, suggesting derivation from the nearby carbonate platform.

Phylum Loricifera Kristensen, 1983

Class, order and family uncertain

\section{Genus Sirilorica Peel, 2010}

Type species. - Sirilorica carlsbergi Peel, 2010, Buen Formation, Sirius Passet Lagerstätte (early Cambrian, Atdabanian; Cambrian Series 2, Stage 3), North Greenland.

\section{Sirilorica pustulosa sp. nov.}

Figure 4

Holotype. - MGUH 29254 from Geological Survey of 
Greenland sample 340103, Sirius Passet, Peary Land, North Greenland. The species is currently known only from part and counterpart of a single specimen.

Type locality and horizon. - Sirius Passet Lagerstätte. Sirius Passet, Peary Land, central North Greenland (latitude $82^{\circ} 47 \cdot 6^{\prime} \mathrm{N}$, longitude $42^{\circ} 13 \cdot 3^{\prime} \mathrm{W}$ ), at an altitude of about $450 \mathrm{~m}$. above sea level. Buen Formation, Cambrian Series 2, Stage 3 (early Cambrian); Atdabanian (Nevadella Zone of North American usage).

Derivation of name. - With reference to the pustulose ornamentation.

Diagnosis. - Species of Sirilorica with numerous, welldeveloped pustules along the hinge zones between the plates of the lorica.

Description. - As in the type species, the lorica consists of two interdigitating circlets of seven elongate, flat, plates which carry one or more broad spines at their spatulate terminations. Individual plates are joined by flexible hinge zones which may be finely papillate or striated but carry evenly spaced, round to elongate, pointed pustules. Soft tissues extending beyond the terminations of the lorica are poorly known. At the inferred anterior in the holotype, a narrow granular zone is succeeded by a poorly defined smooth area, with two (possibly three) preserved denticles located at the boundary between these two zones. The denticles are tear shaped, with a rounded base facing the lorica and a sharp distal point. The denticle surface is marked by three small longitudinal cusps posteriorly, while the distal point is also somewhat raised.

Discussion. - Sirilorica pustulosa sp. nov. is readily distinguished from the type species, $S$. carlsbergi, by the pustules along the hinge zones of the lorica. Only two denticles are clearly preserved in the only known specimen of $S$. pustulosa (Fig. 4C, D) whereas up to six have been described in S. carlsbergi (Peel 2010, fig. 2). In the latter, however, the number of denticles present seems to be a preservational artifact. The denticles in $S$. carlsbergi were described as multicuspidate whereas the holotype of S. pustulosa preserves tear shaped plates carrying raised cusps (Fig. 4C); this difference may also result from differential preservation.

Peel (2010) interpreted Sirilorica as a tubular lorica, although all available specimens are crushed. Typically three (or four) plates on the upper surface overlie four (or three) plates on the undersurface, with the overlapping of the two series producing a complicated lattice pattern. In Sirilorica pustulosa the effect is emphasized by plate margins showing pustules in positive and negative relief, respectively (Fig. 4A, B).
Phylum Arthropoda von Siebiold \& Stannius, 1854

Class, order and family uncertain

\section{Genus Isoxys Walcott, 1890}

Type species. - Isoxys chilhoweanus Walcott, 1890, Chilhowee Group (early Cambrian), Tennessee, U.S.A.

\section{Isoxys sp. \\ Figure 3C}

Figured material. - MGUH 29255 from Geological Survey of Greenland sample 340103, Sirius Passet, Peary Land, North Greenland.

Discussion. - This single fragmentary specimen differs from Isoxys volucris Williams, Siveter \& Peel, 1996 in terms of its size and preservation (Williams et al. 1996, Stein et al. 2010). Isoxys volucris attains a maximum legth of about $2.2 \mathrm{~cm}$, excluding the cardinal spines, whereas Isoxys sp. was 5 to $6 \mathrm{~cm}$ long excluding spines. The preserved surface of the shield valves of Isoxys sp. is also smooth, apart from minor folds, whereas I. volucris typically is highly wrinkled after compaction, with a well developed and conspicuous doublure (Williams et al. 1996, Stein et al. 2010). This contrast between the doublure and the remaining lateral areas of the valves is not seen in Isoxys sp., nor in most of the other species placed within the genus by García-Bellido et al. (2009). Additionally, the single preserved spine of Isoxys sp. is steeply inclined and also relatively more robust than the spines of $I$. volucris. In this respect it is similar to Isoxys glaessneri García-Bellido, Paterson, Edgecombe, Jago, Gehling \& Lee, 2009 from the lower Cambrian Emu Shale Fossil-Lagerstätte of Kangaroo Island, South Australia, although that species is only half the size (García-Bellido et al. 2009).

Phylum uncertain

Class Hyolitha Marek, 1963

Order Hyolithida Sysoiev, 1957

Discussion. - The status of hyoliths as a separate phylum or a class of molluscs remains unresolved; it is discussed from a historical perspective by Malinky \& Yochelson (2007) who favoured the latter assignment.

\section{Genus Trapezovitus Sysoiev, 1958}

Type species. - Trapezovitus sinscus Sysoiev, 1958, early Cambrian (late Atdabanian-early Botomian, according to Missarzhevsky 1989, p. 170) of the Siberian Platform. 


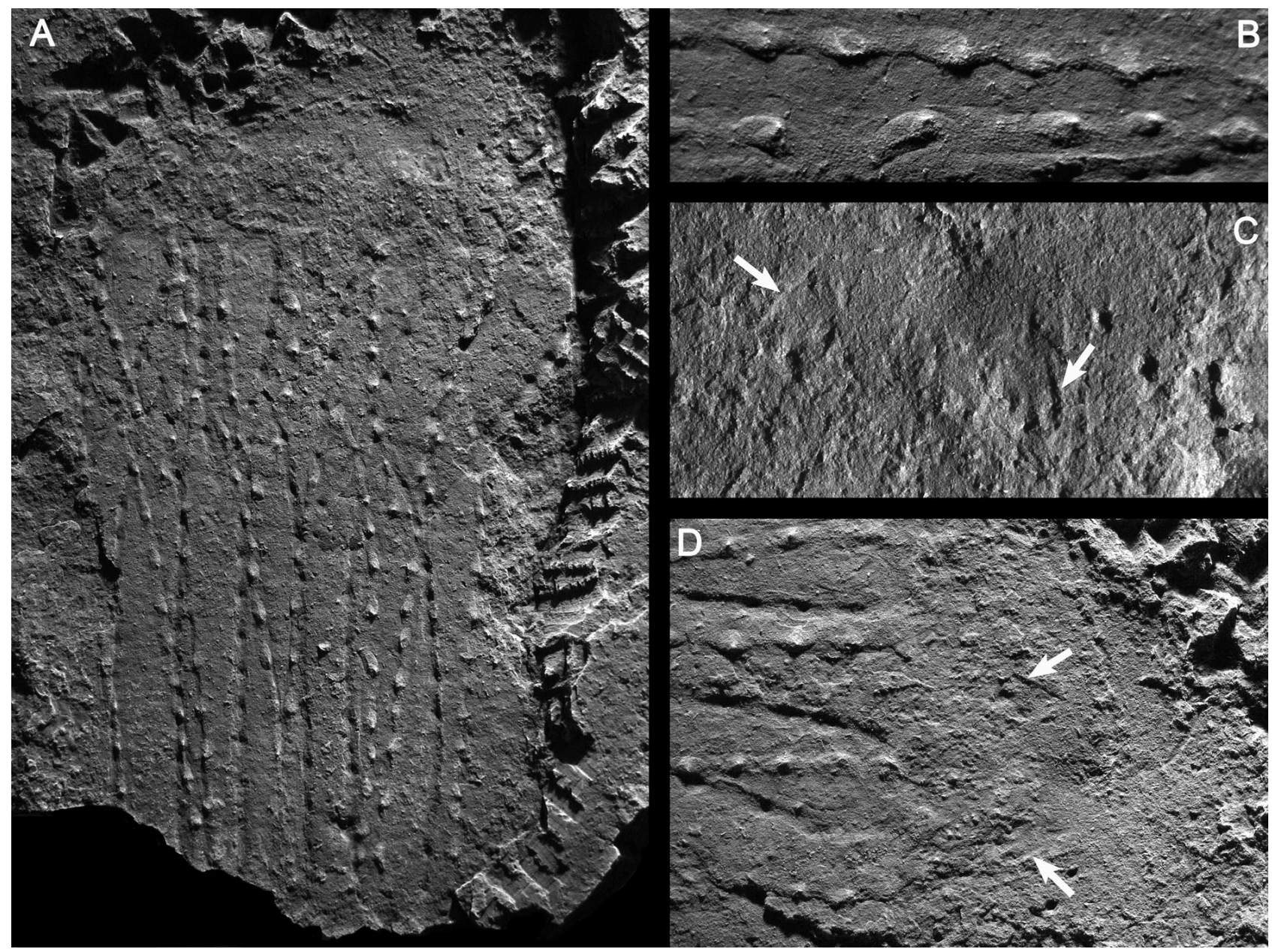

Figure 4. Sirilorica pustulosa sp. nov., Sirius Passet Lagerstätte, Buen Formation, Sirius Passet, Peary Land, North Greenland. Holotype, MGUH 29254. - A - lateral view showing pustulose hinge zones between plates of the lorica, lighting from right, $\times 3.3$. $\bullet \mathrm{B}-\mathrm{detail}$ of hinge zone, $\times 7.5$. $\bullet \mathrm{C}-$ anterior denticles, $\times 7.5$. $\bullet$ D - detail of anterior margin of lorica showing denticles at the junction between the granular zone and the smoother area, to the right, $\times 5$.

\section{Trapezovitus sp.}

Figure 5E, $\mathrm{F}$

Figured material. - MGUH 29256-29257 from Geological Survey of Greenland sample 340103, Sirius Passet, Peary Land, North Greenland.

Description. - Two partly crushed external moulds carry prominent longitudinal ribs on the dorsum which suggest assignment to Trapezovitus. In one specimen the ribbed surface appears to be continuous with a smooth, anteriorly convex, surface representing the operculum (or possibly the projecting ligula of the ventral surface) but a fracture separates the two areas (Fig. 5E). Lateral areas of the conch are incompletely preserved, giving the impression that the operculum is wider than the conch. Eight longitudinal ribs are visible and the tip of the conch is turned up, indicating slight convexity of the ventral surface.
Discussion. - The type species, $T$. sinscus, seems to have a more rapidly expanding shell with fewer longitudinal ribs (Meshkova 1974, Valkov 1975, Meshkova et al. 1983) but other species described by Valkov (1975) are more slender, with more numerous ribs. Trapezovitus sp. appears to have less steeply inclined lateral areas, in cross-section, when compared to described species, but this may be a preservational effect.

\section{Hyolithid sp. \\ Figure 5A-D}

Figured material. - MGUH 29258-29261 from Geological Survey of Greenland sample 340103, Sirius Passet, Peary Land, North Greenland.

Description. - Five specimens preserve helens in position of growth (Fig. 5A-C), while a sixth specimen placed here has the operculum slightly displaced (Fig. 5D). All but one ap- 


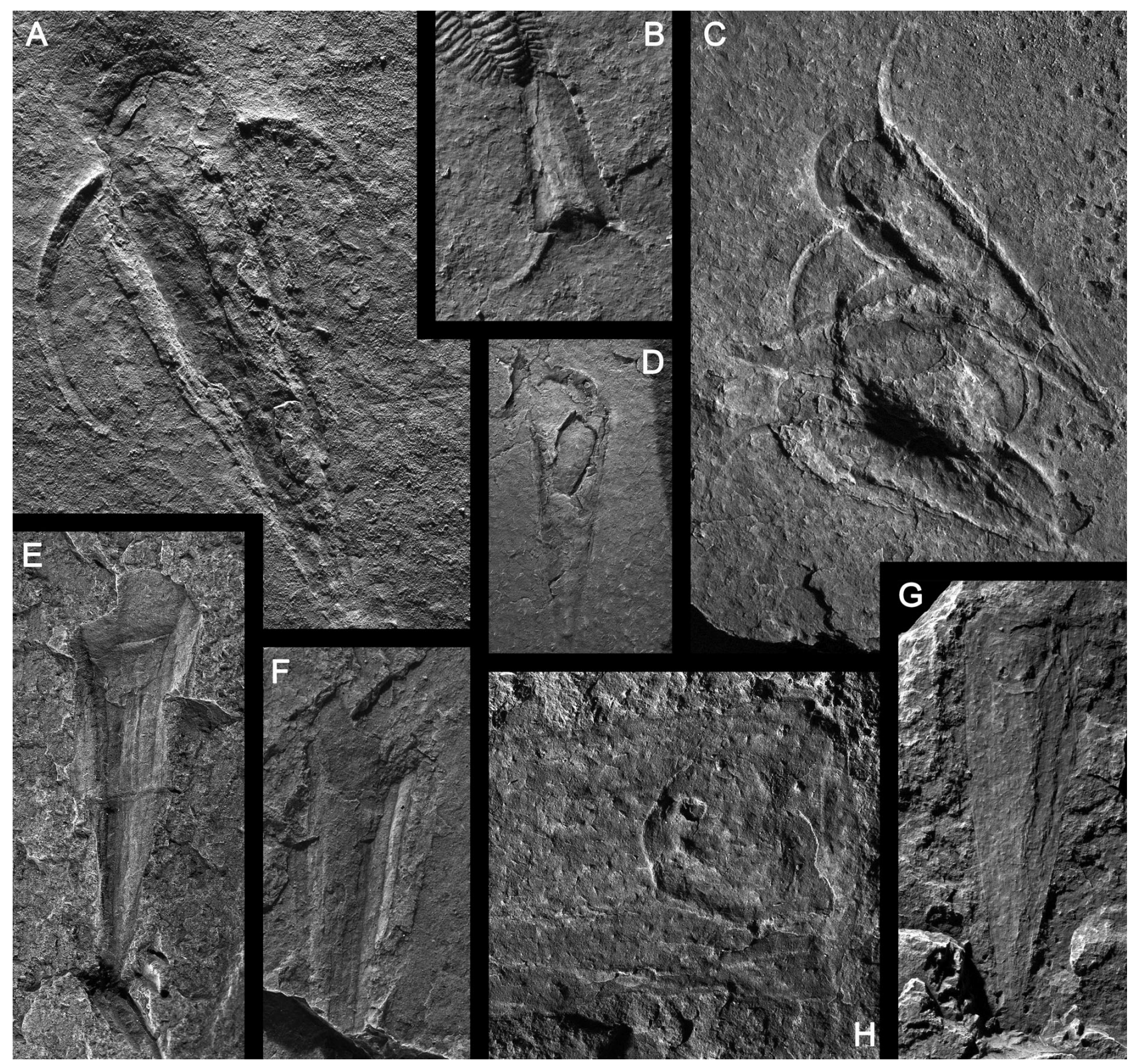

Figure 5. Hyoliths, Sirius Passet Lagerstätte, Buen Formation, Sirius Passet, Peary Land, North Greenland. • A-D - hyolithid sp., A - MGUH 29258 , $\times 7.2$; B - MGUH 29259, ×3.4; C - MGUH 29260, × 4, D - MGUH 29261, ×3.4. • E, F - Trapezovitus sp., E - MGUH 29256, × 4; F - MGUH 29257, $\times 4.7 . \cdot \mathrm{G}, \mathrm{H}-$ orthothecid sp., MGUH 29262, G × 2.5; H - detail of operculum, $\times 7$.

pear to be preserved in dorsal aspect, as composite moulds, but crushing has increased the depression of the lateral slopes relative to the lateral margins and the median dorsal surface. The median dorsal area is flattened (Fig. 5B); no trace of ornamentation remains. The operculum, where present, is poorly differentiated from the conch, dorsally, and the concentric surfaces visible in Fig. 5A, C include portions of the ligula. Paired helens are preserved, either as raised ridges or depressions. Typically, the margin along the convex side is raised relative to that along the concave side, such that the surface slopes towards the postero-lateral areas. In some cases, however, this surface represents the impression of the underside of the helen rather than its upper surface (Fig. 5A, left helen).

Discussion. - Poor preservation prevents precise assignment of this taxon despite the association of all skeletal elements.

The best preserved associations of hyolithid conchs with articulated helens and an operculum from Cambrian strata have been described by Martí Mus \& Bergström (2005) on the basis of specimens from the middle Cambrian of the Czech Republic originally described by Marek (1967, 1972). The specimens are preserved as moulds in three dimensions and exquisite details of the musculature 
and internal structures have been used to elucidate the function of the helens in life. Such detail is not present in the crushed Greenland specimens but the gross form of the conch in the two occurrences is not similar. A conch of comparable width, but with a shorter ligula and more elliptical cross-section, is seen, however, in another Czech middle Cambrian species, Jincelites vogeli Valent, Fatka, Micka \& Szabad, 2009, where helens are preserved but not in articulation with the conch (Valent et al. 2009).

Numerous associations of fully articulated hyolithids from the midddle Cambrian Burgess Shale of British Columbia and the Spence Shale of Utah were described by Yochelson (1961) and Babcock \& Robison (1988). Specimens showing similar proportions to the Sirius Passet material were referred by Babcock \& Robison (1988) to the genus Haplophrentis Babcock \& Robison, 1988 but their dorsal surface carries a median crack interpreted as resulting from a minor internal septum. The conical shield and cardinal shield areas of the operculum ( $c f$. Martí-Mus \& Bergström 2005, text-fig. 1) are clearly visible in the Burgess Shale material (Yochelson 1961) but are not recognised in the poorly preserved Greenland material which also lacks details of shell sculpture. Yochelson (1961) commented on the postero-lateral slope of the flat surface of the helens in specimens from the Burgess Shale which is also a feature of the Greenland specimens. Butterfield \& Nicholas (1996) assigned to Haplophrentis middle Cambrian bedding plane assemblages of articulated hyolithids from the Mount Cap Formation of northwestern Canada, also illustrating finely preserved skeletal elements from macerated samples. Kruse (1998) described helens in an articulated hyolthid from the middle Cambrian of northern Australia.

Articulated hyolithids are less well known from the lower Cambrian. Howell \& Stubblefield (1950) described a specimen from Wales, U.K., with helens and operculum, but it is too poorly preserved to compare with the Greenland specimens. Yochelson (1961, pl. 33, fig. 4) illustrated a poorly preserved specimen from the Kinzers Shale (Botomian; Cambrian Series 2, Stage 4) of Pennsylvania, somewhat younger than the Sirius Passet Lagerstätte (Atdabanian; Cambrian Series 2, Stage 3) in which a single helen is present, although Skinner (2005, p. 173) reported other finds. Of particular interest is the record of Hyolithes czarnae Orłowski \& Waksmundzki, 1986 from the pre-trilobite Cambrian (Series 1, Terreneuvian) of the Holy Cross Mountains of Poland which appears to be the oldest documented association of conch, operculum and helens, although not referable to Hyolithes sensu stricto (compare Malinky 2006). The helens appear to be more robust than in the Greenland hyolithid and the conch has convex sides in dorsal view, in contrast to the straight sides of the narrower specimens from Greenland. The operculum of the latter is poorly known whereas well developed conical and cardinal shields are seen in Hyolithes czarnae (Orłowski \& Waksmundzki, 1986).

\section{Orthothecid sp.}

Figure 5G, H

Figured material. - MGUH 29262 from Geological Survey of Greenland sample 340103, Sirius Passet, Peary Land, North Greenland.

Discussion. - The conch in this single crushed specimen (length $29 \mathrm{~mm}$ ) expands with shallowly concave sides during the first half of its growth, before becoming almost parallel sided near the aperture. The apertural margin is seen beyond the overlying operculum and is slightly expanded medially, with very shallow lateral sinuses. Ornamentation is restricted to a few striations near the tip which are much finer than the longitudinal ribs of Trapezovitus sp. The operculum is poorly preserved and difficult to delimit from the surface of the conch. It carries comarginal growth increments but these do not clearly delimit its margins except along its dorsal margin (adapical as preserved, left in Fig. 5H). This margin is flattened with a cord-like brim and a slight median fold. Although the sides and ventral margin of the operculum are not clearly perceived, it appears small in comparison to the width of the conch, suggesting that the latter was trapezoidal in cross-section.

\section{Acknowledgements}

Expeditions to visit Sirius Passet in 1989, 1991, 1994 and 2006 were supported by a logistic framework established by the former Geological Survey of Greenland (GGU), its successor, the Geological Survey of Denmark and Greenland (GEUS, Copenhagen) and the Danish Polarcenter, Copenhagen. Grants to support field work (1989-94) from the Carlsberg Foundation, Copenhagen, and National Geographic Society, Washington D.C., to J.S.P. and Simon Conway Morris (Cambridge, U.K.) are gratefully acknowledged, as is finance from the Danish Natural Science Research Council to GEUS for field work in 2006 and ongoing financial support from the Swedish Research Council (Vetenskapsrådet). Jan Bergström (Stockholm), Oldřich Fatka (Prague), Simon Conway Morris and Martin Stein (Lawrence, Kansas) kindly provided literature and advice. Journal reviews by Oldřich Fatka and an anonymous referee are gratefully acknowledged.

\section{References}

BABCOCK, L.E. \& PEEL, J.S. 2007. Palaeobiology, taphonomy, and stratigraphic significance of the trilobite Buenellus from the Sirius Passet Biota, Cambrian of North Greenland. Memoirs of the Association of Australasian Palaeontologists 34, 401-418.

BABCOCK, L.E. \& ROBISON, R.A. 1988. Taxonomy and paleobiology of some Middle Cambrian Scenella (Cnidaria) and hyolithids (Mollusca) from western North America. University of Kansas Paleontological Contributions 121, 1-22.

BEDFORD, R. \& BEDFORD, J. 1939. Development and classification 
of Archaeos (Pleospongia). Memoirs of the Kyancutta Museum 6, 67-82.

BLAKER, M.R. 1988. A new genus of nevadiid trilobite from the Buen Formation (Early Cambrian) of Peary Land, central North Greenland. Grønlands Geologiske Undersøgelse Rapport 137, 33-41.

BLAKER, M.R. \& PEEL, J.S. 1997. Lower Cambrian trilobites from North Greenland. Meddelelser om Grønland, Geoscience 35, $1-145$.

BORNEMANN, J.G. 1884. Bericht über Fortsetzung seiner Untersuchungen kambrische Archaeocyathus-Formen und Verwandter Organismen von der Insel Sardinien. Zeitschrift der Deutschen geologischen Gesselschaft 36, 702-706.

BRIGGS, D.E.G., ERWIN, D.H. \& COLLIER, F.J. 1994. The fossils of the Burgess Shale. 238 pp. Smithsonian Institution Press, Washington D.C.

BUDD, G.E. 1993. A Cambrian gilled lobopod from Greenland. Nature 364, 709-711. DOI 10.1038/364709a0

BUDD, G.E. 1995. Kleptothule rasmusseni gen et sp. nov.: an ?olenellinid-like trilobite from the Sirius Passet fauna (Buen Formation, Lower Cambrian, North Greenland). Transactions of the Royal Society of Edinburgh, Earth Science 86, 1-12.

BUDD, G.E. 1997. Stem group arthropods from the Lower Cambrian Sirius Passet fauna of North Greenland, 127-140. In FORTEY, R.A. \& THOMAS, A.H. (eds) Arthropod Relationships. Chapman \& Hall, London.

BUDD, G.E. 1998. Arthropod body-plan evolution in the Cambrian with an example from anomalocaridid muscle. Lethaia 31, 197-210. DOI 10.1111/j.1502-3931.1998.tb00508.x

BUDD, G.E. 1999a. A nektaspid arthropod from the early Cambrian Sirius Passet fauna, with a description of retrodeformation, based on functional morphology. Palaeontology 42, 99-122. DOI 10.1111/1475-4983.00064

BUDD, G.E. 1999b. The morphology and phylogenetic significance of Kerygmachela kierkegaardi Budd (Buen Formation, Lower Cambrian, N Greenland). Transactions of the Royal Society of Edinburgh, Earth Science 89, 249-290.

BUDD, G.E. \& PEEL, J.S. 1998. A new xenusiid lobopod from the Early Cambrian Sirius Passet fauna of North Greenland. Palaeontology 41, 1201-1213.

BUTTERFIELD, N.J. \& NiCHOLAS, C.J. 1996. Burgess Shale-type preservation of both non-mineralizing and 'shelly' Cambrian organisms from the MacKenzie Mountains, Northwestern Canada. Journal of Paleontology 70, 893-899.

CARON, J.-B. 2006. Banffia constricta, a putative vetulicolid from the Middle Cambrian Burgess Shale. Transactions of the Royal Society of Edinburgh: Earth Sciences 96, 95-111.

CHEN, J. 2004. The dawn of the animal world. 367 pp. Jiangsu Publishing House of Science and Technology, Nanjing. [in Chinese]

ChlupéČ, I. \& Kordule, V. 2002. Arthropods of Burgess Shale type from the Middle Cambrian of Bohemia (Czech Republic). Bulletin of Geosciences 77, 167-183.

CONWAY MORRIS, S. 1998. The Crucible of Creation.The Burgess Shale and the Rise of Animals. 242 pp. Oxford University Press, Oxford, New York and Melbourne.

CONwAY MORRIS, S. \& CARON, J.-B. 2007. Halwaxiids and the early evolution of the lophotrochozoans. Science 315, 1255-1258. DOI 10.1126/science. 1137187

CONWAY MORRIS, S. \& Peel, J.S. 1990. Articulated halkieriids from the Lower Cambrian of North Greenland. Nature 345, 802-805. DOI $10.1038 / 345802 \mathrm{a} 0$

CONWAY MORRIS, S. \& PEEL, J.S. 1995. Articulated halkieriids from the Lower Cambrian of North Greenland and their role in early protostome evolution. Philosophical Transactions of the Royal Society of London B 347, 305-358.

DOI $10.1098 /$ rstb. 1995.0029

CONWAY MORRIS, S. \& PEEL, J.S. 2008. The earliest annelids: Lower Cambrian polychaetes from the Sirius Passet Lagerstätte, Peary Land, North Greenland. Acta Palaeontologica Polonica 53, 137-148. DOI 10.4202/app.2008.0110

CONWAY MORRIS, S. \& PEEL, J.S. 2010. New palaeoscolecidan worms from the lower Cambrian: Sirius Passet Fossil-Lagerstätte (North Greenland), Latham Shale (California), and Kinzers Shale (Pennsylvania). Acta Palaeontologica Polonica $55,141-156$.

Conway Morris, S., Peel, J.S., Higgins, A.K., SoPer, N.J. \& DAVIS, N.C. 1987. A Burgess shale-like fauna from the Lower Cambrian of North Greenland. Nature 326, 181-183. DOI $10.1038 / 326181 \mathrm{a} 0$

DALEY, A. \& PEEL, J.S. 2010. A possible anomalocaridid from the Cambrian Sirius Passet Lagerstätte, North Greenland. Journal of Paleontology 84, 352-355. DOI 10.1666/09-136R1.1

DAWSON, J.W. 1896. Additional notes on fossil sponges and other organic remains from the Quebec Group of Little Métis on the lower St. Lawrence; with notes on some of the specimens by Dr. G.J. Hinde. Transactions of the Royal Society of Canada 7(4), $31-55$.

García-Bellido, D.C., Paterson, J.R., Edgecombe, G.D., JAGO, J.B., GEHLING, J.G. \& LEE, M.S.Y. 2009. The bivalved arthropods Isoxys and Tuzoia with soft-part preservation from the Lower Cambrian Emu Bay Shale Lagerstätte (Kangaroo Island, Australia). Palaeontology 52, 1221-1241. DO] 10.1111/j.1475-4983.2009.00914.x

GRANT, R.E. 1836. Animal Kingdom, 107-118. In TODD, R.B. (ed.) The Cyclopaedia of Anatomy and Physiology. Volume 1. Sherwood, Gilbert \& Piper, London.

Hou, X., Aldridge, R.J., BergströM, J., Siveter, D.J., SiveteR, D.J. \& FENG, X.H. 2004. The Cambrian Fossils of Chengjiang, China. The Flowering of Early Animal Life. 233 pp. Blackwell Science Ltd., Malden, Massachusetts.

Hou, X., Bergström, J., WANG, H., Feng, X. \& Chen, J. 1999. The Chengjiang fauna - exceptionally well-preserved animals from 530 million years ago. $170 \mathrm{pp}$. Yunnan Science and Technology Press, Kunming.

HOWELL, B.F. \& STUBBLEFIELD, C.J. 1950. A revision of the north Welsh Conocoryphe viola beds implying a Lower Cambrian age. Geological Magazine 87, 1-16. DOI $10.1017 / \mathrm{S} 0016756800075506$

INESON, J.R. \& PEEL, J.S. 1997. Cambrian shelf stratigraphy of North Greenland. Geology of Greenland Survey Bulletin 173, 1-120.

INESON, J.R. \& PEEL, J.S. In press. Geological and depositional setting of the Sirius Passet Lagerstätte (early Cambrian), North Greenland. Canadian Journal of Earth Sciences.

KRISTENSEN, R.M. 1983. Loricifera, a new phylum with Aschelminthes characters from the meiobenthos. Zeitschrift für zoologische Systematik und Evolutionsforschung 21, 163-180.

DOI 10.1111/j.1439-0469.1983.tb00285.x

KRUSE, P. 1998. Cambrian palaeontology of the eastern Wiso and western Georgina Basins. Northern Territory Geological Survey Report 9, 1-68.

LAgEBRo, L., StEIN, M. \& PEEL, J.S. 2009. A new ?lamellipedian arthropod from the early Cambrian Sirius Passet Fauna of North Greenland. Journal of Paleontology 83, 820-825.

DOI $10.1666 / 09-011.1$ 
LIN, J.-P., ZHAO, Y.-L., RAHMAN, I.A., XIAO, S. \& WANG, Y. 2010. Bioturbation in Burgess Shale-type Lagerstätten - Case study of trace fossil-body fossil association from the Kaili Biota (Cambrian Series 3), Guizhou, China. Palaeogeography, Palaeoclimatology, Palaeoecology 292, 245-256. DOI 10.1016/j.palaeo.2010.03.048

LUO, H., Hu, S. CHEN, L., ZHANG, S. \& TAO, Y. 1999. Early Cambrian Chengjiang fauna from Kunming region, China. 129 pp. Yunnan Science and Technology Press, Kunming, China. [in Chinese]

MALINKY, J. 2006. Revision of Hyolitha from the Ordovician of Estonia. Paläontologische Zeitschrift 80, 88-106.

MALINKY, J.M. \& YOCHELSON, E.L. 2007. On the systematic position of the Hyolitha (Kingdom Animalia). Memoirs of the Association of Australasian Palaeontologists 34, 521-536.

MÁngAnO, G. \& CARON, J.-B. 2009. The trace fossil record of the Burgess Shale, 43. In SMITH, M., O'BRIEN, L. \& CARON, J.-B. (eds) International Conference on the Cambrian Explosion. Abstract Volume. Burgess Shale Consortium, Toronto.

MAREK, L. 1963. New knowledge on the morphology of Hyolithes. Sborník geologických věd, Paleontologie 1, 53-72.

MAREK, L. 1967. The class Hyolitha in the Caradoc of Bohemia. Sborník geologických věd, Paleontologie 9, 51-113.

MAREK, L. 1972. Middle Cambrian Hyolithes: Maxilites gen. n. [Maxillites gen. n. ze středního kambria (Hyolitha)]. Časopis Národního muzea, Oddíl prírodovědný 141, 69-72.

MARTí-Mus, M. \& BERGSTRÖM, J. 2005. The morphology of hyolithids and its functional implications. Palaeontology 48, 1139-1167. DOI 10.1111/j.1475-4983.2005.00511.x

MeshKova, N.P. 1974. Hyolitha, 57-70. In REPINA, L.N., LAZARENKO, N.P., MESHKOVA, N.P., KORSHUNOV, B.I., NIKIFOROV, N.I. \& AKSARINA, N.A. Biostratigrafiya i fauna nizhnego kembriya Kharaulakh (khr. Tuora-Sis). Trudy Instituta Geologii i Geofyziki, Akademiya Nauk SSSR, Sibirskoe otdeleni 235.

MeshKova, N.P., MissarzheVsKy, V.V., SysoieV, V.A. \& VALKOV, A.P. 1983. Phylum Hyolithozoes, 54-95. In SOKOLOV, B.S. \& ZHURAVLEVA, I.T. (ed.) Yarusnoe raschlenenie nizhnego kembriya Sibiri. Atlas okamenelostej. Trudy Instituta Geologii i Geofyziki, Akademiya Nauk SSSR, Sibirskoe otdeleni 558

MISSARZHEVSKY, V.V. 1989. Drevnejshie skeletnye okamenelosti i stratigrafiya pogranichnykh tolsch dokembriya i kembriya. Trudy Ordena Trudovogo Krasnogo Znameni geologicheskogo instituta Akademii Nauk SSSR 443, 1-238.

ORŁOWSKI, S. \& WAKSMUNDZKI, B. 1986. The oldest Hyolitha in the Lower Cambrian of the Holy Cross Mountains. Acta Geologica Polonica 36, 225-231.

PEEL, J.S. 2010. A corset-like fossil from the Cambrian Sirius Passet Lagerstätte of North Greenland and its implications for cycloneuralian evolution. Journal of Paleontology 84, 332-340. DOI 10.1666/09-102R.1

PEEL, J.S. \& INESON, J.R. In press. The Sirius Passet Lagerstätte (early Cambrian) of North Greenland. Palaeontographica canadiana.

PEEL, J.S. \& STEIN, M. 2009. A new arthropod from the lower Cambrian Sirius Passet Fossil-Lagerstätte of North Greenland. Bulletin of Geosciences 84, 625-630. DOI 10.3140/bull.geosci. 1158

RIGBY, J.K. 1986. Cambrian and Silurian sponges from North
Greenland. Grønlands Geologiske Undersøgelse Rapport 126 51-63.

SIEBOLD, K.T.E. VON \& STANNIUS, H.F. 1845. Lehrbuch der vergleichenden Anatomie der wirbellosen Tiere. Von Veit, Berlin.

SKINNER, E.S. 2005. Taphonomy and depositional circumstances of exceptionally preserved fossils from the Kinzers Formation (Cambrian), southeastern Pennsylvania. Palaeogeography, Palaeoclimatology, Palaeoecology 220, 167-192. DOI 10.1016/j.palaeo.2004.09.015

STEIN, M. 2010. A new arthropod from the Early Cambrian of North Greenland, with a 'great appendage'-like antennula. Zoological Journal of the Linnean Society 158, 477-500. DOI 10.1111/j.1096-3642.2009.00562.x

STEIN, M., PEEL, J.S., SiVETER, D.J. \& WILliAMS, M. 2010. Isoxys (Arthropoda) with preserved soft anatomy from the Sirius Passet Lagerstätte, lower Cambrian of North Greenland. Lethaia 43, 258-265. DOI 10.1111/j.1502-3931.2009.00189.x

SYSOIEV, V.A. 1957. K morfologii, sistematicheskomu polozheniu i sistematike chiolotov. Doklady Akademii nauk SSSR 116(2), 304-377.

SYSOIEV, V.A. 1958. Nadotryad Hyolithoidea, 184-190. In ORLOV, Y.A., LUPPOV, N.P. \& DRUSCHITS, V.V. (eds) Osnovy paleontologii, Molluski-golovonogie P. Ammonoidei (Tseratity $i$ ammonity). Vnutrirakovinnye. Prilozhenie: koniknkhii. Gosgeotekhizdat, Moscow.

TAYLOR, R.S. 2002. A new bivalved arthropod from the Early Cambrian Sirius Passet fauna, North Greenland. Palaeontology 45, 97-123. DOI 10.1111/1475-4983.00229

VALENT, M., FATKA, O., MiCKA, V. \& SZABAD, M. 2009. Jincelites vogeli gen. et sp. nov. (Hyolitha) from the Cambrian of the Czech Republic (Př́ibam-Jince Basin, Teplá-Barrandian region). Bulletin of Geosciences 84, 179-184.

DOI 10.3140/bull.geosci.1084

VALKOV, A.K. 1975. Biostratigrafiya i chioliti kembriya severovostoka sibirskoi platformi. 140 pp. Yakutskii filial sibirskogo otdeleniya, Akademii nauk SSSR, Moscow.

VINTHER, J. \& NIELSEN, C. 2005. The Early Cambrian Halkieria is a mollusc. Zoologica scripta 34, 81-89. DOI 10.1111/j.1463-6409.2005.00177.x

WALCOTT, C.D. 1890. The fauna of the Lower Cambrian or Olenellus Zone. Reports of the U.S. Geological Survey 10, 509-763.

WANG, Y., LIN, J.-P., ZHAO, Y.-L. \& ORR, P.J. 2009. Palaeoecology of the trace fossil Gordia and its interaction with nonmineralizing taxa from the early Middle Cambrian Kaili Biota, Guizhou province, South China. Palaeogeography, Palaeoclimatology, Palaeoecology 277, 141-148. DOI 10.1016/j.palaeo.2009.02.017

WANG, Y., ZHAO, Y.-L., LIN, J.-P. \& WANG, P.-L. 2004. Relationship between trace fossil Gordia and medusiform fossils Pararotadiscus from the Kaili biota, Taijiang, Guizhou, and its significance. Geological Review 50, 113-119. [in Chinese]

Williams, M., SiveTER, D.J. \& PEEL, J.S. 1996. Isoxys (Arthropoda) from the Early Cambrian Sirius Passet Lagerstätte, North Greenland. Journal of Paleontology 70, 947-954.

YoCHELSON, E.L. 1961. The operculum and mode of life of Hyolithes. Journal of Paleontology 35, 152-161.

Zhang, X.-G., BergströM, J., Bromley, R.G. \& HoU, X.-G. 2007. Diminutive trace fossils in the Chengjiang Lagerstätte. Terra Nova 19, 407-412. DOI $10.1111 / \mathrm{j} .1365-3121.2007 .00765 . \mathrm{x}$ 